\title{
GAYA HIDUP DAN KELOMPOK REFERENSI TERHADAP KEPUTUSAN PEMBELIAN IPHONE
}

\author{
Amirullah ${ }^{1}$ \\ Muhammad Zulkarnain ${ }^{2}$ \\ Yulina Astuti ${ }^{3}$ \\ e-mail:m.zulkarnain28@gmail.com \\ Prodi Manajemen Sekolah Tinggi Ilmu Manajemen Pase Langsa
}

\begin{abstract}
ABSTRAK
Penelitian bertujuan untuk mengetahui pengaruh gaya hidup dan kelompok referensi terhadap keputusan pembelian iPhone di Kota Langsa. Populasi pada penelitian adalah konsumen iPhone di Kota Langsa dengan jumlah tidak diketahui secara pasti dan tehnik sampel menggunakan purposive sampling dengan jumlah sebanyak 96 responden. Metode analisis data menggunakan persamaan regresi linier berganda, uji $\mathrm{t}$ dan uji $\mathrm{F}$ serta uji koefisien deteminasi $\left(\mathrm{R}^{2}\right)$. Hasil penelitian diketahui bahwa gaya hidup dan kelompok referensi berpengaruh positif dan signifikan terhadap keputusan pembelian iPhone di Kota Langsa. Hasil uji koefisien determinasi sebesar 44,9\% gaya hidup dan kelompok referensi dapat menjelaskan keputusan pembelian iPhone di Kota Langsa.
\end{abstract}

Kata Kunci: Gaya Hidup, Kelompok Referensi dan Keputusan Pembelian

\begin{abstract}
The study aims to determine the effect of lifestyle and reference groups on iPhone purchasing decisions in Langsa City. The population in this study is iPhone consumers in Langsa City with an unknown number and the sample technique using purposive sampling with a total of 96 respondents. Methods of data analysis using multiple linear regression equations, $t$ test and $F$ test and the coefficient of detemination test $\left(R^{2}\right)$. The results of the study note that lifestyle and reference groups have a positive and significant effect on iPhone purchasing decisions in Langsa City. The results of the determination coefficient test of $44.9 \%$ lifestyle and reference groups can explain the iPhone purchase decision in Langsa City.
\end{abstract}

Keywords: Lifestyle, Reference Groups and Purchasing Decisions 


\section{PENDAHULUAN}

Teknologi yang semakin berkembang terutama pada perangkat komunikasi seperti telepon seluler sangat cepat perkembangannya. Perkembangan tersebut diiringi dengan adanya kebutuhan yang semakin penting pada kehidupan manusia sehari-hari. Kepentingan tersebut adalah salah satunya untuk sarana komunikasi setiap dibutuhkan. Telepon selular sebagai alat komunikasi saat ini sangat membantu setiap kegiatan, seperti kegiatan bisnis, pendidikan, rumah tangga, dan perkantoran. Kepentingan tersebut didukung oleh telepon selular melalui voice call, Short Message Service/SMS), surat elektronik (surel/email), media sosial serta penjelajahan informasi lainnya. Telepon selular ini didukung dengan perkembangan teknologi yang terus meningkat dan saat ini disebut dengan telepon pintar (smart phone).

Perkembangan telepon pintar atau smartphone mulai dari spesifikasi dan sistem operasi yang mendukungnya, bentuk, warna, dan tentunya brand yang ternama. Perkembangan alat komunikasi ini yang awalnya hanya untuk panggilan suara dan pesan singkat, saat ini berkembang menjadi melebihi kecanggihan computer dan notebook. Kemudian ketersediaan smartphone di pasar terus beragam mulai dari spesifikasi yang rendah sampai yang tinggi serta mulai dari harga yang sejutaan sampai dengan puluhan juta. Kemudian smartphone yang dibeli oleh konsumen, terdapat yang menginginkan produk dari smartphone yang dianggap berkelas akan menimbulkan gengsi dan kepuasan tersendiri bagi konsumen yang memilikinya.

Produk smartphone yang memiliki brand yang dapat membuat seseorang menimbulkan gengsi tersendiri yaitu iPhone. iPhone merupakan smartphone yang diproduksi dan dipasarkan perusahaan Apple. iPhone menggunakan sistem operasi tersendiri dari iPhone yaitu "iPhone Operation Symbian/IOS)". Sistem operasi ini membedakan produk ini dengan smartphone lain yang umumnya menggunakan Android dan Windows. Kelebihan lain yang membuat orang memiliki gengsi dan memiliki keinginan untuk memiliki iPhone berupa desainnya, kamera kualitas terbaik dan touch id yang aman. Berdasarkan Top Brand Indeks pada tahun 2017 iPhone berada di posisi ke 4 setelah Blackberry, di tahun 2018 berada di posisi Top 2 tetapi tahun 2019 kembali di posisi ke 4 setelah Oppo (www.topbrandindeks, 2020). Tetapi setelah iPhone 11 di pasarkan iPhone menjadi smartphone terpopuler di dunia dengan penjualan mencapai 19,5 juta unit di kuartal I tahun 2020, (https://teknologi.bisnis.com, 2020). Tentunya smartphone ini memiliki kelebihan tersendiri dan menjadi pertimbangan dalam membuat keputusan pembelian. 
Keputusan pembelian yang dilakukan oleh konsumen dipengaruhi berbagai faktor, dapat faktor infernal maupun eksternal. Faktor internal yang ada dalam diri sendiri seperti pola hidup seseorang yang tercermin dari kegiatan atau pekerjaan dan pendapat mengenai sebuah produk. Pola hidup sendiri merupakan suatu cara yang dapat menggambarkan perilaku seseorang, yaitu bagaimana hidup, menggunakan uangnya dan memanfaatkan waktu yang dimilikinya. Konsumen kelas menengah atas lebih suka pada produk yang memiliki fitur beda dan memiliki tingkatan gaya hidup yang lebih tinggi (www.bloter.net,2013). Faktor eksternal dapat berupa kelompok referensi. Kelompok referensi dapat memberikan dampak pada pengambilan keputusan untuk pembelian suatu produk. Orang akan sangat yakin dalam membeli produk bila telah melihat dan mendengar kesaksian dari konsumen yang telah merasa puas atas suatu produk. Informasi yang diberikan oleh kelompok referensi akan berpengaruh besar bagi calon konsumen untuk segera mengambil keputusan. Kelompok referensi menurut Sumarwan (2011) adalah seseorang atau sekelompok orang yang secara nyata mempengaruhi perilaku seseorang.

Perspektif pemasaran kelompok referensi merupakan kelompok dengan fungsi sebagai referensi konsumen dalam membuat keputusan pembelian. Kelompok referensi terdiri dari keluarga, teman, selebriti, pakar atau ahli, orang-orang biasa, para eksekutif perusahaan maupun pegawai biasa. Tetapi pada umumnya kelompok referensi yang menjadi aspirasi yang diikuti adalah kelompok terdekat.

Berdasarkan hasil hasil survey yang dilakukan pada empat toko penyedia iPhone di Kota Langsa dari Bulan Oktober sampai dengan Desember 2020 dengan peningkatan penjualan yang setiap bulannya, seperti pada grafik berikut.

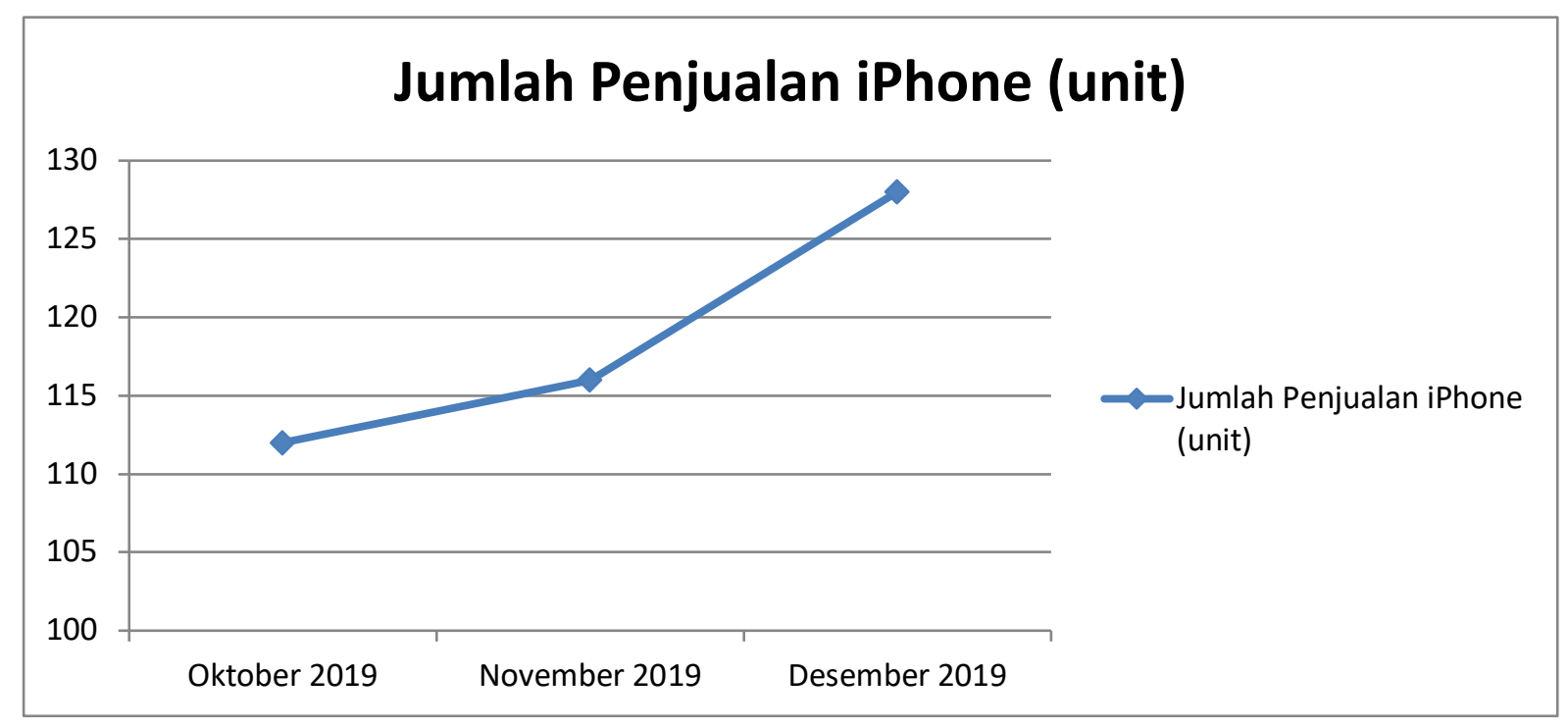

Gambar 1: Jumlah Penjualan iPhone di 4 Toko di Kota Langsa, Januari 2020 
Berdasarkan gambar 1 diketahui bahwa dari 4 toko hasil survey terjadi peningkatan penjualan atau terjadi peningkatan pembelian oleh konsumen. Hasil survey juga diketahui bahwa menurut konsumen membeli iPhone karena adanya kelebihan dari produk ini dan menunjukkan bahwa dengan membeli iPhone konsumen tersebut memiliki kemampuan ekonomi serta dapat memenuhi aktivitas yaitu pekerjaan yang mendukung, hobi, kegiatan sosial, hiburan serta komunitas. Sementara minat yang terpenuhi dapat berupa shoping karena kebutuhan serta opini terhadap ekonomi dan bisnis serta masa depan. Alasan lain menggunakan iPhone karena adanya teman kelompok (grup) yang menggunakan dan menyarankan untuk menggunakan iPhone sehingga kelompok (grup) memiliki kesamaan perangkat komunikasi. Berdasarkan penelitian sebelumnya bahwa gaya hidup dan kelompok referensi berpengaruh positif dan signifikan terhadap keputusan pembelian, (Apriyandani, Yulianto dan Sunarti, 2017), (Putra, 2015), dan (Kholifah dan Rulirianto, 2017). Berdasarkan hal tersebut maka dilakukan penelitian bagaimana pengaruh gaya hidup dan kelompok referensi terhadap keputusan pembelian iPhone di Kota Langsa.

\section{Tinjauan Pustaka Gaya Hidup}

Gaya hidup (lifestyle) adalah pola hidup seseorang di dunia yang tercermin dalam kegiatan, minat, dan pendapat (Kotler dan Keller, 2008). Pendapat lain menyatakan bahwa gaya hidup didefinisikan sebagai pola dimana orang hidup dan menghabiskan waktu, serta uang, (Setiadi, 2010). Sementara Sumarwan (2011) gaya hidup sering digambarkan dengan kegiatan, minat dan opini dari seseorang (aktivitas, keinginan dan opini) dan gaya hidup seseorang biasanya tidak permanen dan cepat berubah, seseorang mungkin dengan cepat mengganti model dan merek pakaiannya karena menyesuaikan dengan perubahan hidupnya.

Setiadi (2010) menyatakan bahwa gaya hidup cenderung mengklasifikasikan konsumen berdasarkan variabel-variabel Aktivitas, Interest/minat dan Opini (AIO). Kemudian gaya hidup diukur dari aktifitas-aktifitas manusia seperti:

1. Pola seseorang dalam menghabiskan waktunya

2. Minat seseorang

3. Pandangan seseorang terhadap diri sendiri dan orang lain.

4. Karakter-karakter dasar seperti tahap yang dilalui seseorang dalam kehidupan (life cycle), penghasilan, pendidikan, dan di mana mereka tinggal. VALS (Value and Lifestyle) adalah 
salah satu contoh pendekatan segmentasi gaya hidup yang lain. Pendekatan ini menggunakan gabungan beberapa teori, yaitu:

a. Teori hirarki kebutuhan manusia (need hierarchy) yang dikembangkan oleh Abraham H. Maslow. Menurut teori ini, ada lima tingkat kebutuhan yang dilalui oleh manusia secara bertingkat yaitu: kebutuhan fisik dasar, rasa aman, memiliki, esteem, dan aktualisasi diri. VALS mengidentifikasi nilai-nilai (values) yang dianut masyarakat pada setiap tingkat kebutuhan tersebut.

b. Teori tentang dorongan-dorongan kepribadian (The inner and outer directed personality theory) yang diperkenalkan oleh Riesman, Glazer dan Denney. Di dalam VALS, terminology other directed diubah menjadi outer directed (dorongan dari luar). Dalam meramalkan perilaku konsumen, para ahli berpendapat bahwa nilai-nilai individu akan menentukan gaya hidup seseorang, dan gaya hidup seseorang akan menentukan konsumsi atau perilaku seseorang. Sebagian ahli memiliki pendapat yang sedikit berbeda. Mereka berpendapat bahwa nilai-nilai individu mempunyai hubungan langsung terhadap perilaku konsumen.

\section{Kelompok Referensi}

Sumarwan (2011) menyatakan bahwa kelompok referensi (reference group) merupakan seorang individu atau sekelompok orang yang secara nyata mempengaruhi perilaku seseorang. Dalam perspektif pemasaran, kelompok referensi adalah kelompok yang berfungsi sebagai referensi bagi seseorang dalam keputusan pembelian dan konsumsi. Sementara Kotler dan Keller, (2008), kelompok referensi adalah semua kelompok yang mempunyai pengaruh langsung atau tidak langsung terhadap sikap atau perilaku orang tersebut. Kelompok yang mempunyai pengaruh langsung disebut kelompok keanggotaan. Menurut Setiadi (2010) sikap seseorang dipengaruhi oleh faktor, yaitu:

1. Pengaruh Keluarga

Keluarga mempunyai pengaruh yang sangat penting dalam keputusan pembelian. Dengan mengabaikan kecenderungan anak usia belasan tahun yang sering memberontak pada orang tua, sebenarnya terdapat hubungan yang kuat antara sikap orang tua dan sikap anaknya.

2. Pengaruh Kelompok Kawan Sebaya 
Banyak studi yang memperlihatkan bahwa kawan sebaya mampu mempengaruhi dalam perilaku pembelian. Pengaruh kelompok kawan sebaya lebih memungkinkan mempengaruhi sikap dan perilaku pembelian dari pada iklan.

3. Pengalaman

Pengalaman masa lalu mempengaruhi sikap terhadap merek. Pengalaman penggunaan suatu merek produk pada masa lalu akan memberikan evaluasi atas merek produk tersebut, bergantung apakah pengalaman itu menyenangkan atau tidak. Jika pengalaman masa lalu itu menyenangkan maka sikap konsumen dimasa mendatang akan positif, tetapi jika pengalaman pada masa lalu itu tidak menyenangkan maka sikap konsumen di masa mendatang pun akan negatif.

4. Kepribadian

Kepribadian konsumen mempengaruhi sikap. Sifat-sifat seperti suka menyerang, terbuka, kepatuhan atau otoritarianisme mungkin mempengaruhi sikap terhadap merek dan produk. Individu yang agresif mungkin lebih mungkin terlibat dalam persaingan olahraga dan akan membeli peralatan yang paling mahal dalam usahanya untuk mengungguli lawannya.

Kelompok referensi dapat diukur dengan indikator:

1. Pengetahuan komunitas mengenai produk

2. Kredibilitas dari komunitas

3. Pengalaman dari komunitas

4. Keaktifan komunitas

\section{Keputusan Pembelian}

Kotler dan Amstrong (2008) menyatakan bahwa keputusan pembelian (purchase decision) konsumen adalah membeli merek yang paling disukai, tetapi dua faktor bisa berada antara niat pembelian dan keputusan pembelian. Faktor pertama adalah sikap orang lain dan faktor kedua adalah faktor situasional. Sementara Suharno dan Sutarso (2010) menyatakan bahwa keputusan pembelian dipengaruhi oleh beberapa faktor, yaitu faktor organisasi, faktor pribadi, faktor individu dan faktor lingkungan. Menurut Setiadi (2010), proses pengambilan keputusan dengan tahapan sebagai berikut:

1. Pengenalan masalah. Proses membeli diawali saat pembeli menyadari adanya masalah kebutuhan. Pembeli menyadari terdapat perbedaan antara kondisi sesungguhnya dan kondisi yang diinginkannya. Kebutuhan ini dapat disebabkan oleh rangsangan internal 
maupun internal dalam kasus pertama dari kebutuhan normal seseorang, yaitu rasa lapar, dahaga, atau seks meningkat suatu tingkat tertentu dan berubah menjadi dorongan.

2. Pencarian informasi. Seorang konsumen yang mulai timbul minatnya akan terdorong untuk mencari informasi lebih banyak. Kita dapat membedakan dua tingkat, yaitu keadaan tingkat pencarian informasi yang sedang-sedang saja yang disebut perhatian yang meningkat.

3. Evaluasi alternatif. Bagaimana konsumen memproses informasi tentang pilihan merek untuk membuat keputusan akhir. Ternyata tidak ada proses evaluasi yang sederhana dan tunggal yang digunakan oleh konsumen atau bahkan oleh satu konsumen pada seluruh situasi membeli.

4. Keputusan pembelian. Pada tahap evaluasi, konsumen membentuk preferensi terhadap merek-merek yang terdapat pada perangkat pilihan. Konsumen mungkin juga membentuk tujuan membeli untuk merek yang paling disukai. Walaupun demikian dua faktor dapat mempengaruhi tujaun membeli dan keputusan membeli.

5. Perilaku sesudah pembelian. Sesudah pembelian terhadap suatu produk yang dilakukan konsumen akan mengalami beberapa tingkat kepuasan atau ketidakpuasan. Konsumen tersebut jua akan terlibat dalam tindakan sesudah pembelian dan penggunaan produk yang akan menarik minat pemasar. Pekerjaan pemasar tidak akan berakhir pada saat suatu produk dibeli, tetapi akan terus berlangsung hingga periode sesudah pembelian.

Indikator untuk mengukur variabel keputusan pembelian terdiri dari:

1. Keputusan pemilihan produk

2. Keputusan pemilihan merek

3. Keputusan pemilihan dialer

4. Saat yang tepat melakukan pembelian

\section{METODE PENELITIAN}

Penelitian ini memiliki variabel terdiri dari gaya hidup dan kelompok referensi sebagai variabel bebas dan keputusan pembelian sebagai variabel terikat. Populasi pada penelitian ini adalah konsumen pengguna iPhone di Kota Langsa yang jumlahnya tidak diketahui secara pasti. Untuk itu sampel menggunakan non probability sampling yaitu setiap elemen dari populasi tidak diberi kesempatan yang sama untuk ditarik menjadi sampel (Sinulingga, 2013). Penentuan sampel pada penelitian ini menggunakan purposive sampling yaitu tehnik penentuan 
sampel dengan pertimbangan tertentu (Sugiyoo, 2010), dan yang menjadikan pertimbangan adalah konsumen iphone dengan jumlah sampel sebanyak 96 responden.

Tehnik Pengumpulan Data

Pengumpulan data dalam penelitian menggunakan:

a. Observasi yaitu tehnik pengumpulan data, dimana peneliti melakukan pengamatan secara langsung ke objek penelitian untuk melihat dari dekat kegiatan yang dilakukan (Arikunto, 2008). Observasi pada penelitian ini pada konsumen Iphone di kota Langsa.

b. Wawancara yaitu tehnik pengumpulan data dengan jalan mengadakan komunikasi dengan sumber data dan komunikasi dilakukan dengan dialog, (Arikunto, 2008). Komunikasi dilakukan kepada konsumen iPhone di Kota Langsa.

c. Kuesioner yaitu sejumlah pertanyaan tertulis yang digunakan untuk memperoleh informasi dari responden dalam arti laporan tentang pribadinya atau hal-hal yang di ketahui (Arikunto, 2008). Kuesioner diberikan kepada konsumen iPhone di Kota Langsa yang terpilih menjadi responden penelitian.

Metode analisis data yang digunakan terdiri dari uji validitas, reliabilitas (pengujian instrumen penelitian), uji regresi linier berganda, uji t dan F serta koefisien determinasi $\left(\mathrm{R}^{2}\right)$.

\section{HASIL PENELITIAN DAN PEMBAHASAN}

1. Hasil penelitian

Uji validitas dan reliabilitas instrument penelitian dapat dilihat pada tabel 1 .

\section{Tabel 1}

Uji Validitas

\begin{tabular}{|l|c|c|c|}
\hline \multicolumn{1}{|c|}{ Variabel/Pernyataan } & $\begin{array}{c}\text { Nilai Corrected } \\
\text { Item-Total } \\
\text { Correlation }\end{array}$ & R tabel & Keterangan \\
\hline Gaya hidup (X1) & 0,862 & 0,361 & Valid \\
P1 & 0,905 & 0,361 & Valid \\
P2 & 0,925 & 0,361 & Valid \\
P3 & 0,667 & 0,361 & Valid \\
\hline Kelompok Referensi (X2) & 0,817 & 0,361 & Valid \\
P4 & 0,668 & 0,361 & Valid \\
P5 & 0,847 & 0,361 & Valid \\
P6 & 0,779 & 0,361 & Valid \\
\hline Keputusan Pembelian (Y) & 0,886 & 0,361 & Valid \\
P7 & & & \\
P8 & & & \\
P9 & & & \\
\hline
\end{tabular}




\begin{tabular}{|l|l|l|l|}
\hline P10 & 0,839 & 0,361 & Valid \\
P11 & 0,830 & 0,361 & Valid \\
P12 & 0,797 & 0,361 & Valid \\
\hline
\end{tabular}

Sumber: Output SPSS

Hasil uji validitas menunjukkan bahwa secara keseluruhan dari setiap pernyataan yang diajukan dinyatakan valid karena Nilai Corrected Item-Total Correlation $>$ R tabel. Selanjutnya dapat diketahui nilai uji reliabilitas.

\section{Tabel 2}

Uji Reliabilitas

\begin{tabular}{|l|c|c|}
\hline \multicolumn{1}{|c|}{ Variabel } & Cronbach's Alpha & R Tabel \\
\hline Gaya hidup & 0,877 & 0,60 \\
\hline Kelompok Referensi & 0,784 & 0,60 \\
\hline Keputusan pembelian & 0,906 & 0,60 \\
\hline
\end{tabular}

Sumber: Output SPSS

Hasil uji reliabilias menunjukkan bahwa ketiga variabel dinyatakan reliable dengan nilai cronbach's alpha $>\mathrm{r}$ tabel.

Uji Regresi Linier Berganda

Hasil penelitian dengan menggunakan analisis regresi linier berganda yang bertujuan untuk mengetahui pengaruh gaya hidup dan kelompok referensi terhadap keputusan pembelian. Hasil uji yang dihitung dengan SPSS dapat dilihat pada tabel berikut.

Tabel 3

Ouput SPSS Regeresi Linier Berganda, Uji t, Uji F dan Koefisien Determinasi

\begin{tabular}{|l|r|r|l|}
\hline \multicolumn{1}{|c|}{ Model } & B & t sig & \multicolumn{1}{|c|}{ keterangan } \\
\hline Constant & 0,676 & 0,092 & \\
\hline Gaya hidup & 0,490 & 0,000 & Signifikan \\
\hline Kelompok referensi & 0,294 & 0,000 & Signifikan \\
\hline R square $\left(\mathrm{R}^{2}\right)$ & 0,449 & Dependent variabel: keputusan pembelian \\
\cline { 1 - 2 } F sig & 0,000 & &
\end{tabular}

Sumber: Output SPSS

Berdasarkan tabel 3 dapat dibuat persamaan regresi linier berganda $Y=0,676+0,490 X 1$ $+0,294 X 2$. Konstanta sebesar 0,676 merupakan keputusan pembelian sebelum dipengaruhi oleh gaya hidup dan kelompok referensi. Koefisien regresi 0,490 merupakan gaya hidup berpengaruh positif terhadap keputusan pembelian dan bila terjadi peningkatan satu skala maka akan meningkatkan keputusan pembelian sebesar 0,490 skala. Kemudian koefisien regresi 0,294 merupakan kelompok referensi yang berpengaruh positif terhadap keputusaan pembelian 
dan bila terjadi peningkatan satu skala maka akan meningkatkan keputusan pembelian sebesar 0,294 skala.

Hasil uji secara parsial diperoleh pada variabel gaya hidup $\mathrm{t} \operatorname{sig}<\alpha 5 \%(0,00<0,05)$ dan dapat dinyatakan bahwa gaya hidup berpengaruh signifikan terhadap keputusan pembelian iPhone di Kota Langsa. Pada variabel kelompok referensi diperoleh t sig $<\alpha 5 \%(0,00<0,05)$ dan dapat dinyatakan bahwa kelompok referensi berpengaruh signifikan terhadap keputusan pembelian iPhone di Kota Langsa. Hasil uji F diperoleh F sig $<\alpha 5 \%(0,00<0,05)$ dan dapat dinyatakan secara simultan gaya hidup dan kelompok referensi berpengaruh signifikan terhadap keputusan pembelian iPhone di Kota Langsa. Hasil uji koefisien determinasi $\left(\mathrm{R}^{2}\right) \mathrm{di}$ peroleh R Square sebesar 0,449. Berdasarkan hasil tersebut maka 44,9\% variabel gaya hidup dan kelompok referensi dapat menjelaskan keputusan pembelian sementara sebesar 55,1\% dipengaruhi oleh variabel lain yang tidak masuk dalam variabel penelitian ini.

\section{Pembahasan}

a. Gaya hidup terhadap keputusan pembelian

Gaya hidup berpengaruh positif dan signifikan terhadap keputuasn pembelian iPhone di Kota Langsa. Hasil ini dikarenakan konsumen iPhone di Kota Langsa memiliki minat untuk dapat memiliki iPhone karena berkaitan dengan kegiatannya, baik untuk berbisnis atau pekerjaan maupun untuk kepentingan berkomunikasi. Selain itu keputusan pembelian iPhone juga dikarenakan dengan memiliki iPhone terpenuhi keinginan untuk memiliki brand ternama dengan kualitas terbaik. Hal ini sesuai dengan penelitian (Apriyandani, Yulianto dan Sunarti, 2017), (Putra, 2015), dan (Kholifah dan Rulirianto, 2017) bahwa gaya hidup berpengaruh positif dan signifikan terhadap keputusan pembelian.

b. Kelompok referensi terhadap keputusan pembelian

Kelompok referensi berpengaruh positif dan signifikan terhadap keputusan pembelian iPhone di Kota Langsa. Hal ini dikarenakan konsumen iPhone di Kota Langsa, menggunakan iPhone karena terdapat kelompok yang menjadi referensi mereka, seperti keluarga, teman dalam satu grup dan terdapat pula yang konsumen yang menjadi referensinya adalah idolanya seperti artis atau aktor saat melihat di sosial media. Hal ini sesuai dengan penelitian (Apriyandani, Yulianto dan Sunarti, 2017), (Putra, 2015), dan (Kholifah dan Rulirianto, 2017) bahwa kelompok referensi berpengaruh positif dan signifikan terhadap keputusan pembelian.

\section{PENUTUP}


Hasil penelitian dan pembahasan diketahui bahwa kedua variabel bebas yaitu gaya hidup dan kelompok referensi memberikan pengaruh positif dan signifikan terhadap keputusan pembelian iPhone di Kota Langsa. Sementara berdasarkan hasil penelitian juga diketahui dari dua variabel tersebut yang paling besar memberikan pengaruh terhadap keputusan pembelian adalah gaya hidup dengan koefisien regresi sebesar 0,490 dan disusul dengan kelompok referensi dengan koefisien regresi sebesar 0,294.

Saran yang dapat disampaikan bahwa gaya hidup dan kelompok referensi memberikan pengaruh positif, untuk itu produsen dan pemasar dari iPhone dapat meningkatkan keputusan pembelian konsumen dengan memanfaatkan gaya hidup dan kelompok referensi konsumen.

\section{DAFTAR PUSTAKA}

Apriyandani, Hendri. Yulianto, Edy dan Sunarti. 2017. Pengaruh Gaya Hidup dan Kelompok Referensi terhadap Keputusan Pembelian (Survei Mahasiswa S1 Fakultas Ilmu Administrasi Angkatan 2014 dan 2015 Universitas Brawijaya Malang yang Membeli dan menggunakan Smartphone iPhone). Jurnal Administrasi Bisnis (JAB). Vol 50. No. 2. Hal: $180-189$

Arikunto, Suharsimi. 2008. Prosedur Penelitian suatu Pendekatan Praktek. Jakarta: Rineka Cipta.

https://teknologi.bisnis.com, iPhone 11 jadi Gawai terpopuler di dunia diunduh 13 Mei 2020.

Kholifah, Fitria Nur dan Rulirianto. 2017. Pengaruh Gaya Hidup dan Kelompok Referensi terhadap Keputusan Pembelian Lipstik Merek Wardah (Studi pada Mahasiswi Program Studi D-IV Manajemen Pemasaran Jurusan Administrasi Niaga Politeknik Negeri Malang). Jurnal Aplikasi Bisnis. Vol 3. No 1. Hal: 147-152.

Kotler, Philip dan Amstrong, Gary. 2008. Prinsip-prinsip Pemasaran. Jakarta: Erlangga.

Kotler, Philip dan Keller, Kevin Lane. 2008. Manajemen Pemasaran. Jakarta: Erlangga.

Putra, Febri Anggara. 2015. Pengaruh Gaya Hidup dan Kelompok Referensi terhaap Keputusan Pembelian Iphone (Studi pada Konsumen iPhone di Universitas Brawijaya). Jurnal Ilmiah Mahasiswa FEB. Vol. 3, No. 1.

Setiadi, Nugroho,J. 2010. Perilaku Konsumen. Jakarta: Kencana Pramedia Group.

Sinulingga, Sukaria. 2013. Metode Penelitian Edisi 3. Medan: USU Press.

Sugiyono. 2010. Metode Kuantitatif, Kualitatif, dan $R \&$ D. Bandung: Alfabeta.

Suharno dan Yudi Sutarso. 2010. Marketing in Practice. Yogyakarta: Graha Ilmu.

Sumarwan, Ujang. 2011. Perilaku Konsumen: Teori dan Penerapan dalam Pemasaran. Bogor: Ghalia Indonesia.

www.bloter.net. Produk iPhone, diunduh 2 Februari 2020. 
Jurnal Ekonomi Perjuangan ( JUMPER )

Volume 2 Nomor 1, Juli 2020

p-ISSN : 2714-8319,e-ISSN: 2714-7452

www.topbrand-award.com, Top Brand Indeks Smartphone. diunduh 2 Februari 2020.

12|Jurnal Ekonomi Perjuangan (JUMPER) 